\title{
Body composition assessment by bioelectrical impedance analysis and body mass index in individuals with chronic spinal cord injury
}

\author{
ERFBM Azevedo ${ }^{1,3}, \mathrm{KC}$ Alonso ${ }^{2}$ and A Cliquet Jr. ${ }^{1,2}$ \\ 1. Biomechanics and Rehabilitation Lab., Department of Orthopedics and Traumatology, Faculty of Medical Sciences, University of \\ Campinas - Unicamp, Campinas, Brazil. \\ 2. Biocybernetics and Rehabilitation Engineering Lab., Department of Electrical Engineering, University of São Paulo \\ 3. E-mail any correspondence to: eliza.azevedo@yahoo.com.br
}

\begin{abstract}
Purpose: To assess body composition and obesity in individuals with spinal cord injury (SCI) who practice and do not practice physical activity using body mass index (BMI) and bioelectrical impedance analysis (BIA). Methods: 39 patients with SCI went through BIA evaluation and BMI was assessed. Patients were divided into four groups according to injury level (paraplegia or tetraplegia) and physical activity achievement (active or inactive). Results: 22 individuals with paraplegia ( 7 active and 15 inactive) and 17 with tetraplegia (5 active and 12 inactive) were evaluated. BMI, fat percentage, fat mass, lean tissue mass, total body water (TBW), and TBW percentage were assessed in groups. Tetraplegic inactive groups showed higher fat percentage featuring obesity. For paraplegic active group mean fat percentage was $19.61 \%( \pm 9.27)$ and mean fat mass was $16.66 \mathrm{~kg}( \pm 9.71)$ and for paraplegic inactive group fat percentage was $23.27 \%( \pm 5.94)$ and fat mass $18.59 \mathrm{~kg}$ $( \pm 7.58)$. For tetraplegic groups in active group the fat percentage was $17.14 \%( \pm 6.32)$ and fat mass was $11.22 \mathrm{~kg}( \pm 5.16)$ and for inactive group mean fat percentage was $33.68 \%( \pm 4.74)$ and fat mass was $25.59 \mathrm{~kg}( \pm 2.91)$. When paraplegic and tetraplegic inactive groups were compared differences were observed in fat percentage $(p=0.0003)$ and fat mass $(p=0.0084)$. Also, when tetraplegic groups (activeXinactive) were compared differences in percentage $(p=0.0019)$ and fat mass $(p=0.034)$ were observed. Only for the paraplegic inactive group BMI result was higher than $25 \mathrm{~kg} / \mathrm{m}^{2}$. Conclusion: BMI does not discriminate between obesity levels in individuals with SCI and physical activity can improve body composition and prevent obesity in SCI patients.
\end{abstract}

Keywords: body composition, fat mass, body mass index, spinal cord injury, physical activity, bioelectrical impedance analysis

\section{Introduction}

Individuals with spinal cord injury (SCI) undergo body composition changes as a consequence of mobility loss and muscular denervation. The changes include decreases in lean tissue mass and bone density and increases in fat mass [1]. Body composition significantly deteriorates during the first six months after injury, lean tissue mass decreases about $9.5 \%[2]$.

Also, due to fat mass increase, diseases like lipid abnormalities, insulin resistance, heart diseases, and carbohydrate intolerance occur prematurely and with higher prevalence in SCI individuals [2-6]. Cardiovascular mortality rate is twice as high in SCI patients than in able- bodied population [7]. However, other studies show that physical activity for individuals with SCI can decrease such risk factors $[8,9]$.

There are several methods to assess body composition and obesity. However, there are not specific methods for individuals with SCI. Studies demonstrate the use of dual Xray absorptiometry (DXA), waist circumference, anthropometric index, bioelectrical impedance analysis (BIA), and body mass index (BMI) in this population $[1,4,10]$.

The World Health Organization (WHO) recommends BMI as a metric to indicate obesity for able-bodied population, with $\mathrm{BMI} \geq 25 \mathrm{~kg} / \mathrm{m}^{2}$ for overweight and $\geq 30$ $\mathrm{kg} / \mathrm{m}^{2}$ for obesity [4]. However, this method does not measure fat directly and its use is questionable in persons with SCI. Nevertheless, it is still used because it is a simple method that only requires mass and height measurements $[4,5]$.

The SCI population has a higher risk to develop chronicle diseases due to the lack of mobility and when this is combine with sedentary lifestyle it could contributes to obesity $[2,8,9]$. Because of the lesion individuals with SCI cannot be evaluated as the general population. So, it is important to evaluate body composition of this population with reliable methods.

BIA is a valid and practical method for assessing obesity and body composition. It estimates physiological parameters such as body water, fat mass, and lean mass using a lowintensity electric current $(80 \mu \mathrm{A}-50 \mathrm{kHz})$ that goes through body impedance offered by tissues. The alternating electric current passes through the body via ECG type skin electrodes and higher impedance is provided by fat mass [11]. However, this method requires a rigid preparation protocol for the exam and it is not specific for SCI population.

Therefore, the aim of the study was to assess body composition and obesity in individuals with SCI (paraplegia and tetraplegia) who practice and do not practice physical activity using BMI and BIA methods and also compare the use of these methods in different SCI groups.

\section{Materials and methods}

Thirty-nine patients, all male, with SCI and lesions over two years old were recruited from the Biomechanics and 
Rehabilitation Laboratory at the University Hospital of UNICAMP. The work was approved by the local Ethics Committee (no 371/2011).

First, all patients were evaluated by AIS (American Spinal Cord Injury Association Impairment Scale) to define their neurologic level and then divided them into four groups according to their injury level (paraplegia or tetraplegia) and physical activity achievement (active those who performed physical activity or inactive those who did not engage in physical activity). For the latter other activities, such as those during conventional rehabilitation, were not considered.

All individuals went through BIA evaluation (Biodynamics ${ }^{\circledR}$ 310e). Before the test, subjects were instructed to fast for at least four hours, not to consume alcohol for 24 hours, not to exercise, and not consume caffeine for 12 hours before the test day. Also, subjects were instructed to drink at least eight glasses of water and were asked to empty their bladder before measurements were taken.

All measurements were conducted by the same investigator to avoid possible measurement errors.

To perform the test, patients were supine in a comfortable position and stayed in this position for at least five minutes before the test began. Four gel electrodes were placed on the right side along the third metacarpal base and between radius and ulna styloid processes and third metatarsal base and between medial and lateral malleoli of ankle. All sites were cleaned with an alcohol swab before attachment of electrodes. These electrodes were connected to the monitor via a sensor cable. Then the equipment emits a low-intensity electric current $(80 \mu \mathrm{A}-50 \mathrm{kHz})$ that goes through the body by measuring the resistance offered by body tissues.

BMI was calculated by dividing the body mass $(\mathrm{kg})$ by height $\left(\mathrm{m}^{2}\right)$.

Data analysis was performed using the Mann-Whitney test. Variables were BMI, fat percentage, fat mass, lean mass, and total body water (TBW) percentage. Confidence intervals (CI) of $95 \%$ were created and a significant level was set at $p \leq 0.05$.

\section{Results}

Twenty-two individuals with paraplegia ( 7 active and 15 inactive) and seventeen individuals with tetraplegia (5 active and 12 inactive) participated in this study.

Lesion level of paraplegic inactive group individuals ranged between $\mathrm{T} 3$ and T8. And out of 15 participants, 12 were classified as AIS A, 2 AIS B and 1 AIS C. Paraplegic active group individuals also presented $\mathrm{T} 3$ and $\mathrm{T} 8$ injury level, but all 7 were classified as AIS A.

In the tetraplegic inactive group lesion levels ranged between C3 and C6 and all 12 participants were classified as AIS A. Tetraplegic active group presented lesion level ranging from C4 to C7. Out of 5 participants, 1 was classified as AIS A, 3 AIS $\mathrm{B}$ and 1 AIS C.
Table 1 shows anthropometric data (age, mass, height and BMI) of all groups, as it can be observed. No differences were observed between groups.

Table 1: Anthropometric data.

\begin{tabular}{|c|c|c|c|c|c|}
\hline \multirow[t]{2}{*}{$\begin{array}{l}\text { Variables } \\
\text { Groups }\end{array}$} & & $\begin{array}{l}\text { Age } \\
\text { (years) }\end{array}$ & $\begin{array}{l}\text { Mass } \\
(\mathrm{kg})\end{array}$ & $\begin{array}{l}\text { Height } \\
\text { (m) }\end{array}$ & $\begin{array}{l}\text { BMI } \\
\left(\mathrm{kg} / \mathrm{m}^{2}\right)\end{array}$ \\
\hline & Mean & 32 & 80.81 & 1.81 & 24.77 \\
\hline \multirow{3}{*}{$\begin{array}{l}\text { Paraplegic } \\
\text { active }\end{array}$} & SD & 6.06 & 17.19 & 0.07 & 4.24 \\
\hline & CI & $\begin{array}{l}26.4- \\
37.6\end{array}$ & $\begin{array}{l}64,91- \\
96.71\end{array}$ & $\begin{array}{l}1.74- \\
1.86\end{array}$ & $\begin{array}{l}20.85- \\
28.69\end{array}$ \\
\hline & Mean & 37.73 & 77.43 & 1.74 & 25.58 \\
\hline \multirow{3}{*}{$\begin{array}{l}\text { Paraplegic } \\
\text { inactive }\end{array}$} & SD & 9.09 & 15.12 & 0.07 & 4.64 \\
\hline & CI & $\begin{array}{l}32.7- \\
42.77\end{array}$ & $\begin{array}{l}69.06- \\
85.81\end{array}$ & $1.7-1.78$ & $\begin{array}{l}23.01- \\
28.16\end{array}$ \\
\hline & Mean & 34 & 63.4 & 1.74 & 20.95 \\
\hline \multirow{3}{*}{$\begin{array}{l}\text { Tetraplegic } \\
\text { active }\end{array}$} & SD & 8.31 & 9.61 & 0.03 & 2.89 \\
\hline & CI & $\begin{array}{l}23.69- \\
44.31\end{array}$ & $\begin{array}{l}51.47- \\
75.33\end{array}$ & $1.7-1.78$ & $\begin{array}{l}17.35- \\
24.54\end{array}$ \\
\hline & Mean & 37.25 & 76.98 & 1.78 & 24.11 \\
\hline \multirow{2}{*}{$\begin{array}{l}\text { Tetraplegic } \\
\text { inactive }\end{array}$} & SD & 9.94 & 10.46 & 0.05 & 2.82 \\
\hline & CI & $\begin{array}{l}30.94- \\
43.56\end{array}$ & $\begin{array}{l}70.33- \\
83.62\end{array}$ & $\begin{array}{l}1.75- \\
1.82\end{array}$ & $\begin{array}{l}22.32- \\
25.89\end{array}$ \\
\hline
\end{tabular}

Abbreviations: SD, standard deviation; CI, confidence intervals; BMI, body mass index

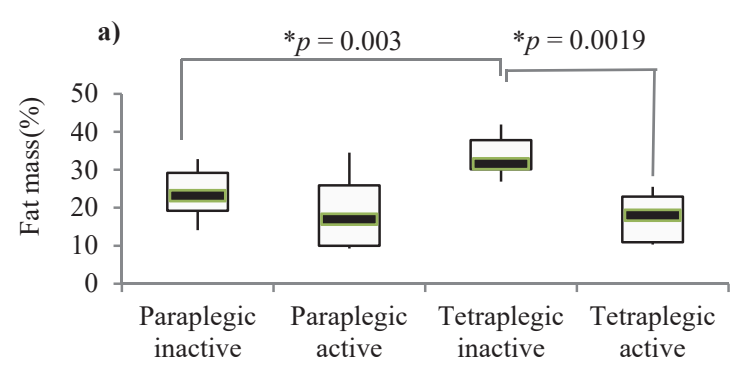

b)

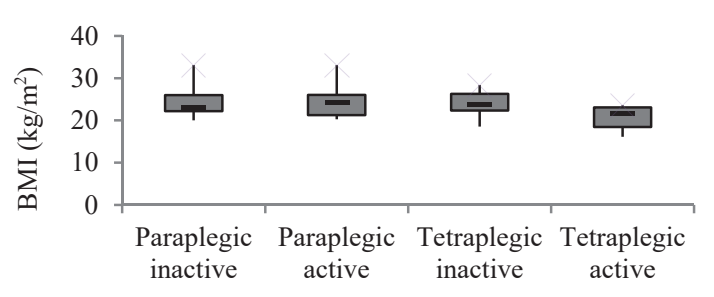

Fig.1: Fat mass percentage (a) and BMI (b) of all groups. When groups were compared differences can be observed in fat mass for paraplegic inactive group $\mathrm{X}$ tetraplegic inactive group $(p=0.003)$ and tetraplegic inactive group $\mathrm{X}$ tetraplegic active group $(p=$ $0.0019)$. 
Table 2: BIA results comparing paraplegic groups (active $\mathrm{X}$ inactive).

\begin{tabular}{|c|c|c|c|c|c|}
\hline \multirow[b]{2}{*}{ Variables } & \multicolumn{2}{|c|}{ Paraplegic } & \multicolumn{2}{|c|}{ Paraplegic active } & \multirow[b]{2}{*}{$\mathrm{p}$ value } \\
\hline & $\begin{array}{l}\text { inactive } \\
\text { Mean } \\
\pm \mathrm{SD}\end{array}$ & CI & $\begin{array}{l}\text { Mean } \\
\pm \mathrm{SD}\end{array}$ & CI & \\
\hline $\begin{array}{l}\text { Fat mass } \\
(\mathrm{kg})\end{array}$ & $\begin{array}{l}18.59 \\
\pm 7.58\end{array}$ & $\begin{array}{l}14.4- \\
22.79\end{array}$ & $\begin{array}{l}16.66 \\
\pm 9.71\end{array}$ & $\begin{array}{l}7.68- \\
25.64\end{array}$ & 0.398 \\
\hline $\begin{array}{l}\text { Lean mass } \\
(\mathrm{kg})\end{array}$ & $\begin{array}{l}58.84 \\
\pm 8.99\end{array}$ & $\begin{array}{l}53.86- \\
63.82\end{array}$ & $\begin{array}{l}64.17 \\
\pm 10.76\end{array}$ & $\begin{array}{l}54.22- \\
74.13\end{array}$ & 0.307 \\
\hline TBW (\%) & $\begin{array}{l}72.15 \\
\pm 3.16\end{array}$ & $\begin{array}{l}70.4- \\
73.9\end{array}$ & $\begin{array}{l}71.11 \\
\pm 2.17\end{array}$ & $\begin{array}{l}69.11- \\
73.12\end{array}$ & 0.549 \\
\hline
\end{tabular}

Abbreviations: SD, standard deviation; CI, confidence intervals;

TBW, total body water

Table 3: BIA results comparing tetraplegic groups (active $\mathrm{X}$ inactive).

\begin{tabular}{|c|c|c|c|c|c|}
\hline \multirow[t]{2}{*}{ Variables } & \multicolumn{2}{|c|}{$\begin{array}{l}\text { Tetraplegic } \\
\text { inactive }\end{array}$} & \multicolumn{2}{|c|}{$\begin{array}{l}\text { Tetraplegic } \\
\text { active }\end{array}$} & \multirow[t]{2}{*}{$\mathrm{p}$ value } \\
\hline & $\begin{array}{r}\text { Mean } \\
\pm \mathrm{SD}\end{array}$ & $\mathrm{CI}$ & $\begin{array}{l}\text { Mean } \\
\pm \mathrm{SD}\end{array}$ & CI & \\
\hline $\begin{array}{l}\text { Fat mass } \\
(\mathrm{kg})\end{array}$ & $\begin{array}{l}25.59 \\
\pm 2.91\end{array}$ & $\begin{array}{l}23.74- \\
27.44\end{array}$ & $\begin{array}{l}11.22 \\
\pm 5.16\end{array}$ & $\begin{array}{l}4.82- \\
17.62\end{array}$ & 0.0034 \\
\hline $\begin{array}{l}\text { Lean mass } \\
(\mathrm{kg})\end{array}$ & $\begin{array}{l}51.37 \\
\pm 9.65\end{array}$ & $\begin{array}{l}45.23- \\
57.5\end{array}$ & $\begin{array}{l}52.18 \\
\pm 6.58\end{array}$ & $\begin{array}{l}44.02- \\
60.34\end{array}$ & 0.792 \\
\hline TBW (\%) & $\begin{array}{l}73.08 \\
\pm 4.62\end{array}$ & $\begin{array}{l}70.15- \\
76.02\end{array}$ & $\begin{array}{l}71.24 \\
\pm 1.2\end{array}$ & $\begin{array}{l}69.75- \\
72.73\end{array}$ & 0.916 \\
\hline
\end{tabular}

Abbreviations: SD, standard deviation; CI, confidence intervals; TBW, total body water

Table 4: BIA results comparing paraplegic active group and tetraplegic active group.

\begin{tabular}{|c|c|c|c|c|c|}
\hline \multirow{3}{*}{ Variables } & \multicolumn{2}{|c|}{ Paraplegic active } & \multicolumn{2}{|c|}{ Tetraplegic } & \multirow{3}{*}{$\begin{array}{l}\mathrm{p} \\
\text { value }\end{array}$} \\
\hline & Mean & $\mathrm{CI}$ & active & & \\
\hline & $\pm \mathrm{SD}$ & & $\begin{array}{l}\text { Mean } \\
\pm \text { SD }\end{array}$ & $\mathrm{CI}$ & \\
\hline $\begin{array}{l}\text { Fat mass } \\
(\mathrm{kg})\end{array}$ & $16.66 \pm 9.71$ & $\begin{array}{l}7.68- \\
25.64\end{array}$ & $\begin{array}{l}11.22 \\
\pm 5.16\end{array}$ & $\begin{array}{l}4.82- \\
17.62\end{array}$ & 0.464 \\
\hline $\begin{array}{l}\text { Lean mass } \\
(\mathrm{kg})\end{array}$ & $64.17 \pm 10.76$ & $\begin{array}{l}54.22- \\
74.13\end{array}$ & $\begin{array}{l}52.18 \\
\pm 6.58\end{array}$ & $\begin{array}{l}44.02- \\
60.34\end{array}$ & 0.74 \\
\hline TBW (\%) & $71.11 \pm 2.17$ & $\begin{array}{l}69.11- \\
73.12\end{array}$ & $\begin{array}{l}71.24 \\
\pm 1.2\end{array}$ & $\begin{array}{l}69.75- \\
72.73\end{array}$ & 0.463 \\
\hline
\end{tabular}

Abbreviations: SD, standard deviation; CI, confidence intervals; TBW, total body water

Table 5: BIA results comparing paraplegic inactive group and tetraplegic inactive group.

\begin{tabular}{|c|c|c|c|c|c|}
\hline Variables & \multicolumn{2}{|c|}{$\begin{array}{l}\text { Paraplegic } \\
\text { inactive }\end{array}$} & \multicolumn{2}{|c|}{$\begin{array}{l}\text { Tetraplegic } \\
\text { inactive }\end{array}$} & $\mathrm{p}$ value \\
\hline $\begin{array}{l}\text { Fat mass } \\
(\mathrm{kg})\end{array}$ & $\begin{array}{l}18.59 \\
\pm 7.58\end{array}$ & $\begin{array}{l}14.4- \\
22.79\end{array}$ & $\begin{array}{l}25.59 \\
\pm 2.91\end{array}$ & $\begin{array}{l}23.74- \\
27.44\end{array}$ & 0.0084 \\
\hline $\begin{array}{l}\text { Lean mass } \\
(\mathrm{kg})\end{array}$ & $\begin{array}{l}58.84 \\
\pm 8.99\end{array}$ & $\begin{array}{l}53.86- \\
63.82\end{array}$ & $\begin{array}{l}51.37 \\
\pm 9.65\end{array}$ & $\begin{array}{l}45.23- \\
57.5\end{array}$ & 0.083 \\
\hline TBW (\%) & $\begin{array}{l}72.15 \\
\pm 3.16\end{array}$ & $\begin{array}{l}70.4- \\
73.9\end{array}$ & $\begin{array}{l}73.08 \\
\pm 4.62 \\
\end{array}$ & $\begin{array}{l}70.15- \\
76.02\end{array}$ & 0.769 \\
\hline
\end{tabular}

Abbreviations: SD, standard deviation; CI, confidence intervals; TBW, total body water

In Figure 1, the difference between groups in fat percentage and BMI can be observed. For able-bodied persons, fat percentage for men should be $\leq 20 \%$ and $\mathrm{BMI}<25 \mathrm{~kg} / \mathrm{m}^{2}$. Paraplegic and tetraplegic inactive groups presented higher values of fat percentage $(23.27 \% \pm 5.94[\mathrm{CI}=19.98-26.56]$ and $33.68 \% \pm 4.74 \quad[\mathrm{IC}=30.66-36.69]$, respectively). Paraplegic inactive group also presented higher BMI $(25.58$ $\left.\mathrm{kg} / \mathrm{m}^{2} \pm 4.64[\mathrm{CI}=23.01-28.16]\right)$. For tetraplegic inactive group BMI was $24.11 \mathrm{~kg} / \mathrm{m}^{2} \pm 2.82(\mathrm{CI}=22.32-25.89)$. For paraplegic active group fat mass was $19.61 \% \quad \pm 9.27$ $(\mathrm{CI}=11.04-28.19)$ and BMI was $24.77 \mathrm{~kg} / \mathrm{m}^{2} \pm 4.64$ $(\mathrm{CI}=20.85-28.69)$. And for tetraplegic active group fat mass was $17.14 \% \pm 6.32(\mathrm{CI}=9.29-24.99)$ and $\mathrm{BMI}$ was 20.95 $\mathrm{kg} / \mathrm{m}^{2} \pm 2.89(\mathrm{CI}=17.35-24.54)$.

In Tables 2, 3, 4 and 5 BIA results are shown and compared: fat mass $(\mathrm{kg})$, lean tissue mass $(\mathrm{kg})$, and TBW percentage in four groups.

\section{Discussion}

BIA has shown to be a reliable, feasible, and practical method towards assessing obesity in persons with SCI, as also demonstrated in other studies [4]. Mojtahedi et al (2009) reported BIA as a reliable method when compared to others. Spungen et al (1995) also reported BIA as a reliable method because this technique is based on the specific electrical characteristics of biological tissue and the reliability of this technique should not be altered with SCI, thereby providing an accurate assessment of body composition. Moreover, BIA also measures TBW (total body water), which is an important component of lean tissue and with this result dehydration or edema can be observed in patients. Individuals with SCI commonly present edema in lower limbs [3]. Normal TBW results are $69 \%$ to $75 \%$ of lean tissue, values that were found in all groups of this research.

The major obesity cause among people with SCI is the decrease in lean tissue and bone mineral density and increase in fat mass, the transition from lean tissue to fat occurring. In this study, subjects who did not performed physical activities showed higher fat percentage, mostly in the tetraplegic group, was also observed in McDonald et al (2007) study, that used DXA to compare body composition in children and adolescents with SCI.

Individuals that performed physical activity in both groups presented normal values of fat percentage, which implies that physical activity can reduce the risk of obesity in persons with SCI.

Individuals with tetraplegia showed higher differences in fat percentage and fat mass when comparing active versus inactive groups, probably due to the active group being composed mostly by incomplete lesion patients, unlike an inactive group that was composed exclusively by complete lesion patients. However, in a study done by Spungen et al (2003) no significant differences were found in fat percentage between complete and incomplete individuals with SCI. So, differences may also have occurred due to lack of mobility of the inactive group of patients, because individuals with tetraplegia are more dependent and move less, different from the individuals in the active group who performed physical activity. 
When individuals were compared by injury level (paraplegia vs. tetraplegia) a significant difference was shown between inactive groups. Patients with tetraplegia presented higher fat percentage than persons with paraplegia, which can also be explained by the lack of mobility of individuals with tetraplegia. Patients with paraplegia are more independent and use their arms more for daily living activities, such as pushing a wheelchair and making transfers, while individuals with tetraplegia do not place these exercise demands on their arms. However, no significant differences were found when active groups were compared, showing that physical activity can definitely improve body composition.

Some studies have reported that BMI underestimates obesity in individuals with SCI $[1,4,5,10,12]$. This was also observed in the present study. Tetraplegic inactive group showed BMI $<25 \mathrm{~kg} / \mathrm{m}^{2}$, which is considered normal, and fat percentage higher than $20 \%$, indicating obesity. WHO reports that men with $\mathrm{BMI} \geq 30 \mathrm{~kg} / \mathrm{m}^{2}$ exhibit fat percentage $\geq 25 \%$. However, this was not observed in this research, as in Jones et al (2003) study, that compared DXA with BMI in men with SCI and scored normal BMI results with high fat percentages. Buchholz and Bugaresti (2005) also reported through a review of several methods to measure body composition in individuals with SCI that BMI is an inconsistent method to detect obesity in SCI patients when compared to fat percentage. Also, they found that BMI average of these patients was 20 to $27 \mathrm{~kg} / \mathrm{m}^{2}$, results consistent with those observed in the present study.

Finally, concerning SCI, individuals who do not perform physical activity, especially tetraplegics, due to lack of mobility, show increase risk of obesity with high fat percentage and fat mass.

\section{Conclusion}

In SCI population BMI does not adequately discriminate obesity, BIA being a more reliable physiological measurement.

In addiction, individuals who do not perform physical activity showed higher fat percentages, thus demonstrating that physical activity can improve body composition and consequently obesity in individuals with SCI.

\section{Acknowledgements}

The authors would like to thank CAPES (Ministry of Education, Brazil).

\section{Conflict of Interest}

The authors declare no conflict of interest.

\section{References}

1. Spungen, AM, Baurman, WA, Wang, J, Pierson, RN Jr. Measurement of body fat in individuals with tetraplegia: a comparison of eight clinical methods. Paraplegia. 1995; 33: 402-408. http://dx.doi.org/10.1038/sc.1995.90
2. Spungen, AM, Adkins, RH, Stewart, CA, Wang, J, Pierson, RN, Waters, RL, Baurman, WA. Factors influencing body composition in persons with spinal cord injury: a crosssectional study. J Appl Physiol. 2003; 95: 2398-2407. http://dx.doi.org/10.1152/japplphysiol.00729.2002

3. Buchholz, AC, McGillivray, CF, Pencharz, PB. The use of bioelectrical impedance analysis to measure fluid compartments in subjects with chronic paraplegia. Arch Phys Med Rehabil. 2003; 84: 854-861. http://dx.doi.org/10.1016/S0003-9993(02)04950-X

4. Eriks-Hoogland, I, Hilfiker, R, Baumberger, M, Balk, S, Stucki, G, Perret, C. Clinicall assessment of obesity in persons with spinal cord injury: validity of waist circumference, body mass index and anthropometric index. The Journal of Spinal Cord Medicine. 2011; 34: 416-422. http://dx.doi.org/10.1179/2045772311Y.0000000014

5. Jones, LM, Legge, M, Goulding, A. Healthy body mass index value often underestimate body fat men with SCI. Arch Phys Med Rehabil. 2003; 4: 1068-1071. http://dx.doi.org/10.1016/S0003-9993(03)00045-5

6. McDonald, CM, Abresch-Meyer, AL, Nelson, MD, Widman, LM. Body mass index and body composition measures by dual x-ray absorptiometry in patients aged 10 to 21 years with spinal cord injury. The Journal of Spinal Cord Medicine. 2007; 30: 5097-5104.

7. Maggioni, M, Bertoli, S, Margonato, V, Merati, G, Veicsternas, A, Testolin, G. Body composition assessment in spinal cord injury subjects. Acta Diabetol. 2003; 40: 5183 5186. http://dx.doi.org/10.1007/s00592-003-0061-7

8. Pain, LR, Schreiber R,Matos-Souza, JR, Silva, AA, Campos, LF, Azevedo, ER, Alonso, K, de Rossi, G, Etchebere, M, Gorla, JI, Cliquet, A Jr, Nadruz, W Jr. Oxidized lowdensity/lipoprotein, matrix-metalloproteinase- 8 and carotid atherosclerosis in spinal cord injured subjects. Artherosclerosis. 2013: 341-345.

9. de Rossi, G, Matos-Souza JR, Costa e Silva, AD, Campos, LF, Santos, LG, Azevedo, ER, Alonso, KC, Paim, LR, Schreiber R, Gorla JI, Cliquet, AJr, Nadruz, WJr. Physical activity and improved diastolic functional in spinal cord injured subjects. Med Sci Sports Exerc. 2013.

10. Buchholz, AC, Bugaresti, JM. A review of body mass index and waist circumference as markers of obesity and coronary heart disease risk in persons with chronic spinal cord injury. Spinal Cord. 2005; 43: 513-518. http://dx.doi.org/10.1038/sj.sc.3101744

11. Cornish, B. Bioimpedance analysis: scientific background. Lymphatic Research and Biology. 2006; 4: 47-50. http://dx.doi.org/10.1089/lrb.2006.4.47

12. Mojtahedi, MC, Valentine, RJ, Evans, EM. Body composition assessment in athletes with spinal cord injury: comparison of field methods with dual-energy X-ray absorptiometry. Spinal Cord. 2009; 47: 698-704. http://dx.doi.org/10.1038/sc.2009.20 